\title{
The Musk-Rat in Britain
}

\section{By Prof. James Ritchie}

$I^{N}$ recent months a great deal has been written about the musk-rat in Britain, but too much attention cannot be focused upon its presence and the possibilities of its presence. Besides, a special scientific interest is attached to its story, apart from the economic problems to which it has given rise, for we are watching to-day, from its beginning, the development of an example of the untoward spread and destructiveness of an animal introduced into a new environment, which will take its place with the notorious examples of the brown rat in Europe and the rabbit in Australia.

The interest in the breeding of wild animals for their fur which had been aroused in Europe by the value of the pelts and the success of American experiments, was intensified in Great Britain after the War, since fur-farming, as a new, interesting, and presumably profitable occupation, seemed to offer a way out of the difficulties of unemployment or uncongenial employment. It began with the development of highly specialised breeds of rabbits, led to the introduction of silver foxes for the breeding of which there were already in Great Britain in 1929 thirty-two farms with a stock of eight hundred foxes, and at length brought the musk-rat or musquash (Odonatra zibethica). The danger of the arrival of the musk-rat ought to have been foreseen and provided against, for its introduction to the upper valley of the Elbe in Bohemia in 1905 had in twenty years caused serious trouble and entailed much expense throughout great stretches of the valleys of the Elbe and the Danube and their tributaries.

Nevertheless, in 1927, musk-rats were imported for breeding purposes to England and Scotland, and although the value of the imported stock as a rule ensured that in these and later importations care was taken to enclose the animals, in one case at least the musk-rats were turned down on the banks of a stream in order to colonise the area. But whether enclosed or not, musk-rats possess a wanderlust, and their habit of burrowing makes them difficult animals to confine by any simple system of enclosure, a fact which was not sufficiently realised in the early days. So that each established colony, except where it was enclosed in escape-proof pens, became a potential centre of distribution. It is said that in the spring of 1931, before the Government had taken any steps in the matter, nearly two hundred people in Britain were keeping musk-rats.

Now it must be admitted, in partial justification of the delayed action of the Government departments concerned, that there was no certainty that the musk-rat would thrive under wild conditions in Britain. Central Europe held its warning, but in most of their native haunts in North America muskrats have shown no undue tendency to increase or spread, nor have the stocks introduced to Finland done so. In the former region, natural control is exercised by carnivorous animals, the mink subsisting very largely upon musk-rats during the winter, while a less share in their destruction is taken by coyotes and lynxes; in the latter region, perhaps unfavourable climate and topography take the place of biological control. In Britain it almost required an experiment to test the possibilities, and such experiments were carried out in the enclosed marshes in which some breeders had liberated their stock. Unfortunately, undesigned experiments came thick and fast owing to escapes, and it was soon apparent that in the absence of biological control, climate and other fac. tors in environment favoured undue multiplication.

Too late in the day to gain an immediately effective hold over the musk-rats in Britain, Parliament passed the "Destructive Imported Animals Act" of 1932, which, with subsequent Orders made by the Minister of Agriculture and Fisheries and the Secretary of State for Scotland, imposed restrictions upon the importation and the keeping of these animals. Since the "MuskRats (Importation and Keeping) Order" of March 31,1932 , no licence has been granted for importation, and fourteen licences have been granted for keeping (two of which have become void), under which the animals must be kept in specially constructed pens and must not be kept in the open. On the premises so licensed there are at present about 226 musk-rats. On March 14, a further Order was issued prohibiting absolutely as from April 1, unless Parliament resolves to the contrary, the importation into, and keeping within, Great Britain of musk-rats.

Before the passing of the Act, musk-rats had established themselves in several areas where they have increased and whence they have spread over considerable tracts of country. So that in England wild individuals have been found in Yorkshire, it is said in three of the home counties (Surrey, Kent and Essex) as well as in the Fen district, but the great centre of dispersal has been the Shrawardine Pool, in Shropshire, where on a marshy area of sixty-five acres, two hundred individuals were turned down in an enclosure in 1929, bred freely and, inevitably, contributed a quota of 'escapes'. Radiating from that centre, about seventy miles of the Severn and its tributaries, from Pool Quay to Leighton, have been colonised, and the developments in Montgomeryshire and Shropshire and their immediate surroundings threaten any counties connected therewith by waterways. So far, however, the Ministry of Agriculture and Fisheries has not yet been able to verify any serious case of infestation outside the Severn area, although with so rapidly breeding a creature any local colony may flare up as a new centre of increase and distribution.

In Scotland musk-rats were known to be free in Kincardineshire, the northern limit, although a 
locality in southern Aberdeenshire has been suspected, and they are said to have been seen at Thornhill, Dumfriesshire, the southern limit, but the main region of infestation lies in the Midlands, in Perthshire and Stirlingshire, where they may be present in any district which is connected by waterways with the River Allan. In the enclosure at Whitemoss Loch, Dunning, there are about a thousand musk-rats. Since the passing of the Act, more than sixteen hundred individuals have been killed in England, and about a hundred in Scotland.

A difficulty in discovering the exact whereabouts of the musk-rats is that of identification on sight, yet it is of the highest importance that their presence or suspected presence should be reported at once to the local authority and the Government department of agriculture. Two British animals are occasionally confused with the musk-rat, the

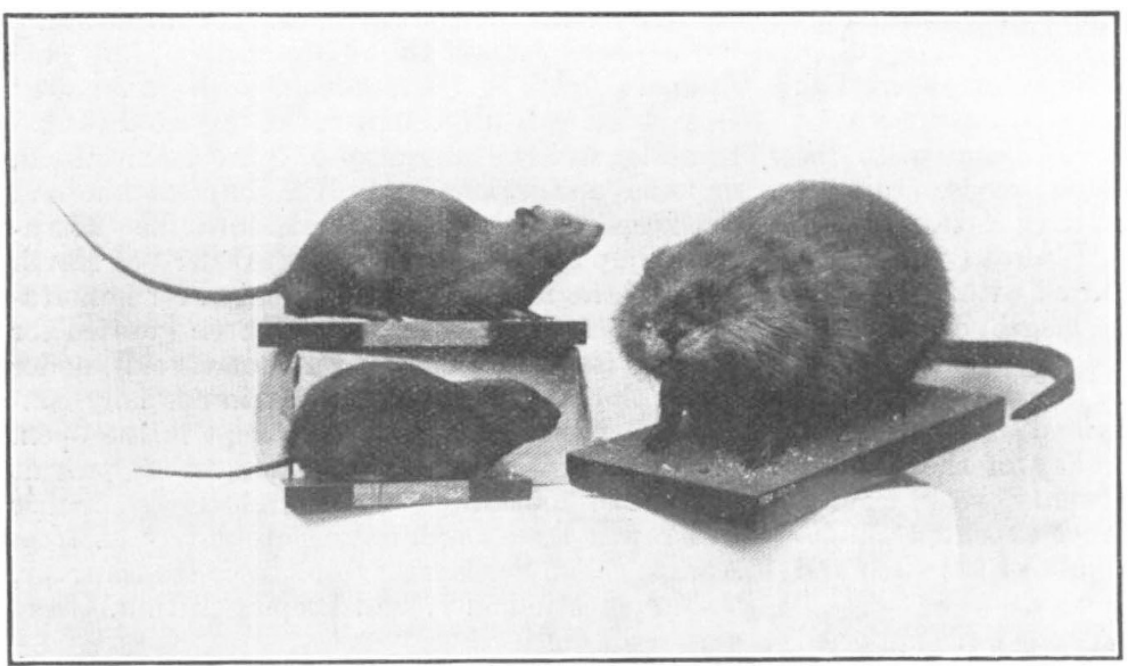

FIG. 1. Right, musk-rat ; top left, common brown rat; bottom left, water-vole. illustrated, from Scottish localities; a deep shelter channel cut to give screened access between waterway and feeding ground (Fig. 2), and, most characteristic at this time of the year, the mounds of rushes, grass, leaves and twigs (Fig. 3), which stand three or four feet above the level of the marsh, and are the 'lodges' or joint food-stores and dwellinghouses in which many individuals congregate during the winter months.

The remaining activities of the musk-rat are for the most part invisible, but nevertheless in them lies the great danger of its presence. It lives mainly upon aquatic vegetation, although on the Continent it has damaged green and root crops, and it also eats animal food such as fishes and molluscs; but the loss from these sources is not likely to be very serious. On the other hand, in a country such as Great Britain, with extensive valleys and waterways kept from flooding by natural or artificial embankments, its burrows are a permanent and serious source of danger. The musk-rat is never found at any great distance from water, and in the banks of the streams it frequents it drives multitudes of burrows, since each nest-cavity has its own connexions. The burrows open beneath the water level and the excavated earth is deposited in the bed of the stream, so that unlike the mole's tunnelling, that of the musk-rat leaves no apparent traces. An emban $\mathrm{km}$ en t apparently common brown rat and the water-rat or watervole. Accordingly a photograph of these three species is reproduced (Fig. 1), from specimens in the Royal Scottish Museum, as the simplest means of showing their differences. The first obvious character is size: the musk-rat is larger than either, 22 inches from snout to tip of tail when full-grown, although exceptionally large brown rats have measured 19 and 20 inches. A second characteristic is the long, dense, rich brown fur, the musquash of furriers, composed of a close under-coat and longer glistening guard-hairs, giving the creature a more robust and 'dumpy' appearance than the sleek brown-rat or water-vole. A final safe distinguishing mark is the tail, which, instead of being round, is flat, compressed sideways, and since it is hairless looks and feels like a narrow black razor-strop. A close inspection would show that the hind feet are large and partly webbed.

Unfortunately, it is rarely that musk-rats show themselves during the daytime even when they are in numbers, so that other signs of their presence must be looked for. Two of these are sound may be honeycombed with cavities, ready to give way on any undue pressure, with what consequences in some localities one can imagine. Here lies another sign of occupation not to be disregarded. Every broken bank in any situation near water should be examined to see if the collapse was due to burrowing, and a distinct musky odour in such place, due to a secretion of the perineal glands of the occupants, should be an aid to identification.

Invisible occupation and spread, extensive undermining of embankments, and a gift of rapid multiplication, for there may be from three to five litters in a year each with six to eight young on an average, combine to make the musk-rat a very dangerous invader.

The danger is realised by many, but it cannot be too widely known. An official of the Canadian Pacific Railway Co. has stated that, in America, apart from damage to canal systems, the creatures "have been responsible for the subsidence of enormous concrete structures, such as head-gates, dams and pool walls, whilst similar timber struc- 
tures have been completely washed out following the operations of a rat colony in their vicinity" (Field, Dec. 17, p. 931, 1932).

What can be done to meet the need of the case? In America musk-rats are easily caught by trapping, and the letter in the $F$ ield referred to above and another (Dec. 24, p. 966) give excellent summaries of the methods of using traps. But the position in America is a little different; there the musk-rat does no harm in many areas and is an annual source of income, so that the trapper has no wish seriously to deplete the breeding stock. In Great Britain the only aim must be extermination. The departments of agriculture are doing their best, by propaganda against the pest, by the employment of trappers, and by the engagement of Continental experts familiar with the methods employed in Central Europe. These are reported to be confident that "given the men, the means and the time, a properly organised campaign can clear the country". But the condition of Central Europe, with its $100,000,000$ musk-rats steadily increasing in numbers and range in spite of every effort, casts some doubt upon the prophecy.

Trapping is necessary but it is not enough, and unconsidered measures run a risk of doing more

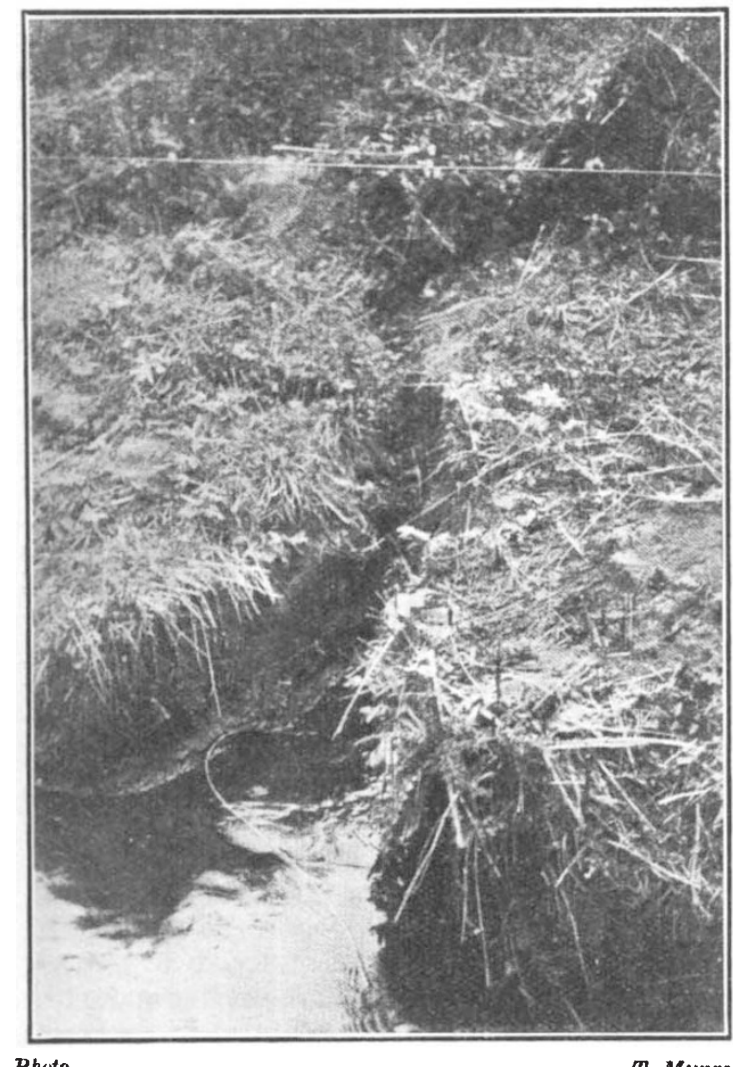

FIG. 2. Screened access between waterway and feeding ground.

harm than good. Recently the Ministry of Agriculture and Fisheries advised the destruction of vegetable growths in the Thames, on the ground that the removal of a favourite food would prevent the settling down of the musk-rats and lead to the use of the streams only as highways. But a present need is to restrict the distribution of the animals and to discourage the use of highways to new areas, and, apart from that, the destruction of water weeds is likely to affect seriously the

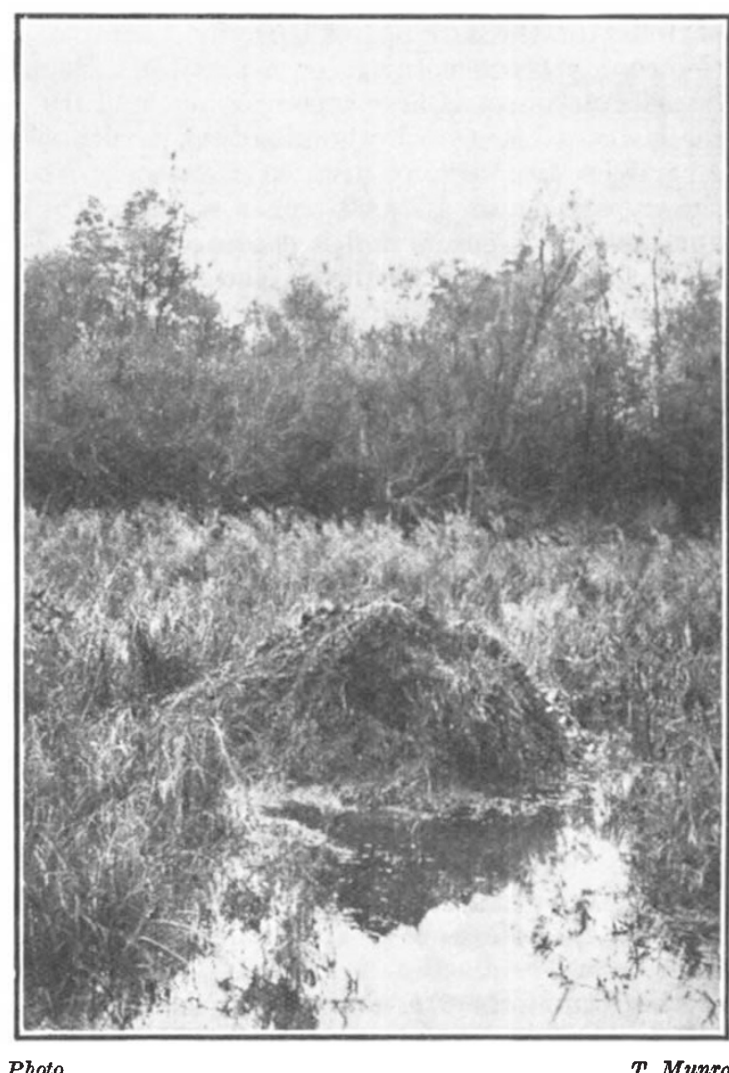

FIG. 3. 'Lodge' or joint food-store and dwelling-house.

invertebrate fauna and the shelter of the river and, through these, the valuable fish fauna.

The Scottish Department of Agriculture, in addition to the employment of trappers, offers a reward of $5 s$. for the killing of musk-rats in certain areas, possibly a useful means of obtaining early information regarding new distribution, and it has tested a mode of destruction which seems to have much in its favour. Trapping is a device against individuals, but in winter the lodges are inhabited by congregations of individuals, which offer a target in the life-history against which every effort of control should be concentrated. The bombing of lodges by miniature bombs, or even the dynamiting of large enclosed areas frequented by many musk-rats, so that they should either be killed outright or disabled by the concussion, ought to be fruitful in resuits. Any and every reasonable means must now be taken to exterminate this destructive alien, while it is still restricted to a few limited areas. Central Europe points not only to the danger of overwhelming multiplication, but also to the need of devising new and more drastic methods of attack against the pest. 